\title{
Effect of egg weight and oviposition time on hatch ability and post hatch performance of Japanese quail (Coturnix coturnix japonica)
}

\author{
L. T. *Egbeyale, H. O. Fatoki and O. A. Adeyemi
}

Department of Animal Production and Health, Federal University of Agriculture, P.M.B.

2240, Abeokuta, Nigeria.

Corresponding author: *egbevalelt@funaab.edu.ng.

\begin{abstract}
A total of three hundred (300) Japanese quail eggs were used to study the effect of oviposition time and egg weight on hatchability and post-hatch performance. The eggs were grouped into two (2) of 150 eggs based on the oviposition time of Morning and Afternoon. The eggs in each group (150) were further sub-grouped based on the egg weights of 8 to 10 grams designated as small sized and 10.1 to 12 grams designated as big size in a $2 \times 2$ factorial design trial of 4 treatments. Each treatment had seventy five (75) eggs each with three replicates. The four treatments groups were; Big Morning, Small Morning, Big Afternoon, Small Afternoon. Each treatment group was replicated three times with each replicates consisting of twenty-five (25) eggs. Hatchability parameters were determined during incubation period of 18 days. The quail chicks were fed ad-libitum and the post- hatch performance was studied for eight (8) weeks. The data generated were subjected to a one-way analysis of variance. Oviposition time and size of the egg significantly $(p<0.05)$ affected the average hatch weight. The effect of interaction of oviposition time and egg size on post-hatch performance did not have any significant $(p>0.05)$ influence. Oviposition time had a positive correlation $(p<0.05)$ with egg weight, egg weight loss, percent egg weight loss and fertility percentage but negatively correlated with average hatch weight and hatchability percentage. Meanwhile egg size had a positive significant $(p<0.01)$ correlation with average hatch weight. It was concluded that eggs ranging between 10.1 to 12 grams will produce higher hatch weight. However, setting of Japanese quail eggs ranging between 8 to 12 grams irrespective of oviposition time could not affect post-hatch performance of the chicks.
\end{abstract}

Keywords: egg weight, oviposition time, hatchability Japanese quail

\section{Introduction}

In Nigeria, chicken appears to be the most common of all the avian species. However, alternative production of poultry meat and egg within a relative shorter time and cheaper cost has been found in Japanese quail (Ojo et al., 2011). Japanese quail are relatively in-expensive to maintain and some 8 to 10 quails can occupy the same space as one chicken (Woodard et al., 1973). Japanese quail (Coturnix coturnix japonica), the smallest farm avian farmed specie is getting important for commercial egg and meat production. It has marked advantage such as its fast growth, early sexual maturity, high rate of egg production, short generation interval and short incubation period (Reddish et al., 2003). Depending on the day length, some 
female start laying at about 35 days of age with an average of 40 days of age and come to peak of production by 50 days of age. Quail hen can lay up to 280-300 eggs in their first year (Metin, 2007) hence has become a pilot animal in the field of research (Cerit, 1997).

Egg weight is one of the important indices for measuring egg quality characteristics. Ayorinde and Olagbuyiro (1991) reported the findings of their studies on clutch size and oviposition time on egg weight and concluded that egg weight was not significantly affected by different time of lay. Moreover, most of investigators revealed However, Johnston and Gous (2007) reported that egg weight of the commercial laying birds was influenced by the time of lay. Pavlovski et al. (2000) also reported that fowl eggs laid in the afternoon had better shell quality characteristics than those of the morning while Patterson (1997) showed that Japanese quail egg weight was higher in the morning and declined by 2 to 9 grams per egg per day between 5:00 hr and 18:00 hr.

Research has shown that time of oviposition affects quality of egg. Many studies conducted indicated that eggs laid early morning are heavier than those of the day time (Tůmová et al., 2009). On the other hand, a number of studies have shown that eggs have better quality characteristics when laid in the afternoon (Tumová and Ebeid, 2005; Tumová et al., 2007). The most influential egg parameters that influence hatchability are: weight, shell thickness and porosity, shape index (described as maximum breadth to length ratio) and the consistency of the contents. Hatchability for small eggs is lower than medium and large eggs (King'ori, 2011).

Hence there is a need to investigate the effect of egg weight and oviposition time on the hatchability and post hatch performance of Japanese quail.

\section{Materials and Methods}

Source of Experimental Eggs

A total of three hundred (300) hatching Japanese quail eggs were collected at different oviposition time (morning and afternoon) from an existing flock at Akobo in Ibadan, Oyo State, Nigeria and were incubated at the Federal University of Agriculture Abeokuta-Leventis Foundation of Nigeria (FUNAAB-LFN) Agro Allied Hatchery, Kotopo, Abeokuta for incubation.

Experimental Site

The experiment was carried out at the Teaching and Research Farm Directorate (TREFAD) of the Federal University of Agriculture, Abeokuta, Nigeria. The area lies on latitude $7^{\circ} 13^{\prime} 49.46 \mathrm{EN}$, longitude $3^{\circ}$ 26' 11.98EE, 76m above the sea level and located in the tropical rainforest vegetation zone with an average temperature of $34.7^{0} \mathrm{C}$.

\section{Experimental Design}

Three hundred Japanese quail eggs were grouped into two groups of 150 eggs each based on the oviposition time of morning and afternoon. The eggs in each group (150) were further divided into two sub-groups of small size eggs (8-10 g) and big size eggs $(10.1-12 \mathrm{~g})$ to make a $2 \times 2$ factorial experimental layout of four (4) treatments. Each treatment comprised of seventy-five (75) eggs each. The four treatment groups were designated Big Morning (BM), Small Morning (SM), Big Afternoon (BA), Small Afternoon (SA) with each group replicated three times. There were 25 eggs in a replicate.

Management of Quail eggs and chicks

The eggs were set with broad ends upward to prevent rupture of air cell in an Electric Western incubator. Each egg was numbered prior to setting in a separate compartment to represent a replicate for ease of data 
collection. The eggs were fumigated using potassium permanganate $\left(\mathrm{KMnO}_{4}\right)$ and formaldehyde in the ratio of $1: 2$ before setting them in the incubator. Egg turning was automatic on hourly basis. This was to prevent developing embryos from adhering to the shell and to ensure uniform distribution of nutrients. A total of 231 Japanese quail chicks were hatched and used in the experiment. The quail chicks brooded for two weeks using charcoal as source of heat. They were fed ad libitum on a commercial starter feed from 0-4 weeks and growers mash for $5-8$ weeks of age. Fresh clean, cool water was also supplied daily.

Data Collection

Determination of Incubation Weight Loss and fertility

The eggs were weighed before setting into the incubator and on the $14^{\text {th }}$ day of incubation (i.e candling date). Weight loss was determined using the formula below:

Weight loss (g)

$=$ Initial weight - final weight

Weight loss \%

$=$ weight loss $(\mathrm{g}) \times 100$

Initial weight

The percentage fertile eggs were determined using the formula below:

Fertility \%

$=$ number of fertile eggs $\times 100 /$

Number of eggs set

\section{Hatchability}

The eggs were weighed to determine the average initial weight of the eggs before setting into the incubator. On the $17^{\text {th }}$ day of incubation, the number of hatched chicks and unhatched eggs were counted separately. The hatchability was determined using the formula below: Hatchability \% $=$ number of chicks hatched $\times 100 /$ Number of fertile eggs
Growth Performance Characteristics Average feed intake, body weight and body weight gain were measured weekly. Feed conversion ratio was calculated by calculating the ratio of feed intake to weight gained.

Data Analysis

Data collected were subjected to 2-way analysis of variance in a $2 \times 2$ factorial experimental (SAS 1999). Significant differences among treatment means were determined using Duncan Multiple Range Test as contained in Statistical Software package.

\section{Results}

The main effect of oviposition and egg size on hatchability parameters is shown in Table 1. The initial egg weight ranged from $9.47 \mathrm{~g}$ (small egg size) to 10.91g (big egg size). The result showed that the initial afternoon egg weight $(10.29 \pm 0.82 \mathrm{~g})$ was significantly $(p<0.05)$ increased by oviposition time when compared with the initial egg weight (10.09 g) which were collected in the morning. The mean values for the final egg weight, fertility percentage, hatchability percentage and average hatch weight were not significantly $(p>0.05)$ influenced by oviposition time. The hatchability percent of the eggs collected in the morning was $89.25 \pm 8.48 \%$ while those collected in the afternoon was $88.25 \pm 4.12 \%$. The eggs collected in the morning had average hatch weight of $6.01 \pm 0.44 \mathrm{~g}$ while those collected in the afternoon recorded mean weight of $5.90 \pm 0.44 \mathrm{~g}$. The result also showed that the final egg weight of big eggs were significantly $(\mathrm{p}<0.05)$ heavier compared to those of small size eggs. Also the average hatch weight $(6.31 \pm 0.10 \mathrm{~g})$ of the big egg size was significantly $(p<0.05)$ heavier compared with the average hatched weight $(5.60 \pm 0.29 \mathrm{~g})$ of small eggs. The average 
Effect of egg weight and oviposition time on post hatch perform ance of Japanese quail

Table 1: Main effect of oviposition and egg size on incubation loss

\begin{tabular}{lllll}
\hline & \multicolumn{2}{c}{ Oviposition Time } & \multicolumn{2}{c}{ Egg Size } \\
Parameters & Morning & Afternoon & S mall & Big \\
\hline Initial egg weight (g) & $10.09 \pm 0.76^{\mathrm{b}}$ & $10.29 \pm 0.82^{\mathrm{a}}$ & $9.47 \pm 0.14^{\mathrm{b}}$ & $10.91 \pm 2.95^{\mathrm{a}}$ \\
Final egg weight (g) & $8.46 \pm 0.66$ & $8.61 \pm 0.72$ & $8.10 \pm 0.33^{\mathrm{b}}$ & $8.97 \pm 0.64^{\mathrm{a}}$ \\
Egg wei ght loss (g) & $1.63 \pm 0.54$ & $1.67 \pm 0.61$ & $1.37 \pm 0.27$ & $1.94 \pm 0.63$ \\
Egg weight loss (\%) & $16.05 \pm 4.71$ & $16.14 \pm 5.09$ & $14.45 \pm 2.95$ & $17.74 \pm 5.74$ \\
Fertility (\%) & $88.33 \pm 8.55$ & $90.00 \pm 4.20$ & $84.67 \pm 9.61$ & $88.67 \pm 3.93$ \\
Hatchability (\%) & $89.25 \pm 8.48$ & $88.25 \pm 4.12$ & $87.92 \pm 6.76$ & $89.58 \pm 6.49$ \\
Average hatch weight (g) & $6.01 \pm 0.44$ & $5.90 \pm 0.44$ & $5.60 \pm 0.29^{\mathrm{b}}$ & $6.31 \pm 0.10^{\mathrm{a}}$ \\
\hline
\end{tabular}

Mean in the same row with different superscripts $a$ and $b$ differ signi ficantly $(\mathrm{P}<0.05)$

hatch weight was significantly influenced $(p<0.05)$ by the interaction between oviposition time and egg weight and ranged from $5.51 \pm 0.09$ to $6.32 \pm 0.11 \mathrm{~g}$ (Table 2).

The oviposition time had no effect ( $\mathrm{p}>0.05$ ) on all the parameters measured while the egg size had significant $(p<0.05)$ effect on both the initial weight of the chicks and the body weight at first egg (Table 3). The average initial body weight of the chicks from big eggs which was $6.55 \pm 0.19 \mathrm{~g}$ while that of small sized eggs was $5.74 \pm 0.08 \mathrm{~g}$. The body weight $(157.58 \pm 9.20 \mathrm{~g})$ at first egg of big eggs was higher than $139.38 \pm 10.87 \mathrm{~g}$ which was recorded for their counterpart from small sized eggs.

The result in Table 4 showed the effect of interaction between oviposition time and egg size on post hatch performance. The mean values for initial body weights were significantly $(\mathrm{p}<0.05)$ different and ranged from $5.67 \pm 0.06 \mathrm{~g}$ (small eggs laid in the afternoon) to $6.63 \pm 0.08 \mathrm{~g}$ (big eggs laid in the afternoon). Other parameters monitored were not significantly $(\mathrm{p}<0.05)$ different. The result of correlation showed in the Table 5 revealed that oviposition positively correlated $(\mathrm{p}<0.05)$ with all the parameters except the average hatch weight and percent hatch which were negatively correlated. The egg size positively correlated with all the parameters. The result revealed that the egg size significantly $(\mathrm{p}<0.01)$ positively correlated with the initial egg weight, final egg weight and the average hatch weight. The egg weight loss had a significantly $(\mathrm{p}<0.01)$

Table 2: Effect of interaction between oviposition and egg size on hatchability measurements

\begin{tabular}{llllll}
\hline & \multicolumn{2}{c}{ Morning } & & \multicolumn{2}{c}{ Afternoon } \\
\cline { 2 - 3 } \cline { 5 - 6 } Parameters & Small Morning & Big Morning & & Small Afternoon & Big Afternoon \\
\hline Initial egg weight (g) & $9.39 \pm 0.05^{\mathrm{c}}$ & $10.78 \pm 0.05^{\mathrm{b}}$ & & $9.55 \pm 0.17^{\mathrm{c}}$ & $11.03 \pm 0.14^{\mathrm{a}}$ \\
Final egg weight (g) & $8.01 \pm 0.44$ & $8.91 \pm 0.55$ & & $8.10 \pm 0.23$ & $9.03 \pm 0.84$ \\
Egg weight loss (g) & $1.38 \pm 0.42$ & $1.88 \pm 0.60$ & & $1.35 \pm 0.08$ & $2.00 \pm 0.79$ \\
Egg weight loss (\%) & $14.74 \pm 4.51$ & $17.37 \pm 5.47$ & & $14.16 \pm 1.05$ & $18.11 \pm 7.20$ \\
Fertility (\%) & $78.67 \pm 10.07$ & $88.00 \pm 4.00$ & & $90.67 \pm 4.62$ & $89.33 \pm 4.62$ \\
Hatchability (\%) & $87.47 \pm 9.72$ & $91.03 \pm 8.71$ & & $88.37 \pm 4.39$ & $88.13 \pm 4.81$ \\
Average hatch weight $(\mathrm{g})$ & $5.69 \pm 0.43^{\mathrm{b}}$ & $6.32 \pm 0.11^{\mathrm{a}}$ & & $5.51 \pm 0.09^{\mathrm{b}}$ & $6.30 \pm 0.15^{\mathrm{a}}$ \\
\hline
\end{tabular}

Mean in the same row with different superscripts $a, b$ and $c$ differ significantly $(\mathrm{P}<0.05)$ 
Table 3: Main effect of oviposition time and egg size on post hatch performance

\begin{tabular}{lcccc}
\hline & \multicolumn{2}{c}{ Oviposition Time } & \multicolumn{2}{c}{ Egg Size } \\
Parameters & Morning & Afternoon & Small & Big \\
\hline Initial body weight (g/bird) & $6.15 \pm 0.42$ & $6.15 \pm 0.56$ & $5.74 \pm 0.08^{\mathrm{b}}$ & $6.55 \pm 0.19^{\mathrm{a}}$ \\
Final body weight (g/bird) & $162.50 \pm 30.62$ & $164.18 \pm 10.74$ & $162.50 \pm 32.27$ & $164.18 \pm 3.35$ \\
Weight gain (g/bird/day) & $2.79 \pm 0.55$ & $2.82 \pm 0.19$ & $2.79 \pm 0.58$ & $2.82 \pm 0.05$ \\
Age at first egg (day) & $51.25 \pm 5.91$ & $48.25 \pm 6.85$ & $46.00 \pm 6.48$ & $53.50 \pm 2.89$ \\
Body weight at first egg(g) & $144.08 \pm 15.32$ & $152.88 \pm 11.71$ & $139.38 \pm 10.87^{\mathrm{b}}$ & $157.58 \pm 9.20^{\mathrm{a}}$ \\
Egg wei ght first laid(g) & $8.55 \pm 1.14$ & $7.83 \pm 0.75$ & $7.85 \pm 1.18$ & $8.53 \pm 0.72$ \\
Feed intake (g/bird/day) & $2.89 \pm 0.16$ & $2.66 \pm 0.38$ & $2.85 \pm 0.21$ & $2.71 \pm 0.39$ \\
Feed conversion ratio (FCR) & $1.06 \pm 0.16$ & $0.95 \pm 0.18$ & $1.05 \pm 0.20$ & $0.96 \pm 0.15$ \\
\hline Mean in the same row with different superscripts a and b differ signi ficantly $(\mathrm{P}<0.05)$
\end{tabular}

Table 4: Effect of interaction between oviposition time and egg size on post hatch performance

\begin{tabular}{lcccc}
\hline & \multicolumn{2}{c}{ Morning } & \multicolumn{2}{c}{ Afternoon } \\
Parameters & Small & Big & Small & Big \\
\hline Initial body weight (g/bird) & $5.82 \pm 0.03^{\mathrm{b}}$ & $6.48 \pm 0.29^{\mathrm{a}}$ & $5.67 \pm 0.06^{\mathrm{b}}$ & $6.63 \pm 0.08^{\mathrm{a}}$ \\
Final body weight (g/bird) & $162.50 \pm 53.03$ & $162.50 \pm 0.00$ & $162.50 \pm 17.68$ & $162.85 \pm 4.74$ \\
Weight gain (g/bird/day) & $2.80 \pm 0.95$ & $2.79 \pm 0.01$ & $2.80 \pm 0.32$ & $2.85 \pm 0.08$ \\
Age at first egg (day) & $49.00 \pm 8.49$ & $53.50 \pm 3.54$ & $43.00 \pm 4.24$ & $53.50 \pm 3.54$ \\
Body weight at first egg(g) & $135.00 \pm 14.14$ & $153.15 \pm 13.22$ & $143.75 \pm 8.84$ & $162.00 \pm 0.71$ \\
Egg weight first laid(g) & $8.20 \pm 1.56$ & $8.90 \pm 0.99$ & $7.50 \pm 1.13$ & $8.15 \pm 0.07$ \\
Feed intake (g/bird/day) & $2.91 \pm 0.27$ & $2.89 \pm 0.05$ & $2.79 \pm 0.21$ & $2.53 \pm 0.57$ \\
Feed conversion ratio (FCR) & $1.08 \pm 0.27$ & $1.03 \pm 0.02$ & $1.01 \pm 0.19$ & $0.89 \pm 0.22$ \\
\hline
\end{tabular}

Mean in the same row with different superscripts a and $\mathrm{b}$ differ signi ficantly $(\mathrm{P}<0.05)$

Table 5: Correlation coefficient of hatchability parameters

\begin{tabular}{|c|c|c|c|c|c|c|c|c|c|}
\hline & Oviposition & Egg size & $\begin{array}{l}\text { Initial egg } \\
\text { weight (g) }\end{array}$ & $\begin{array}{l}\text { Final egg } \\
\text { weight } \\
\text { (g) }\end{array}$ & $\begin{array}{l}\text { Egg weight } \\
\text { loss }\end{array}$ & $\begin{array}{l}\text { Egg weight } \\
\text { loss } \%\end{array}$ & $\begin{array}{l}\text { Fertility } \\
\%\end{array}$ & $\begin{array}{l}\text { Ave. Hatch } \\
\text { weight }\end{array}$ & $\%$ Hatch \\
\hline Oviposition & 1 & & & & & & & & \\
\hline Egg size & 0.0000 & 1 & & & & & & & \\
\hline Initial egg weight & 0.1344 & $0.9824 * *$ & 1 & & & & & & \\
\hline Final egg weight & 0.1206 & $0.6809^{* *}$ & $0.7112^{* *}$ & 1 & & & & & \\
\hline Egg weight loss & 0.0405 & 0.5387 & 0.5266 & -0.2231 & 1 & & & & \\
\hline Egg weight loss \% & 0.0089 & 0.3683 & 0.3494 & -0.4089 & $0.9791^{* *}$ & 1 & & & \\
\hline Fertility $\%$ & 0.4767 & 0.2860 & 0.3673 & 0.3372 & 0.1016 & -0.0009 & 1 & & \\
\hline Ave. Hatch weight & -0.1255 & $0.8702 * *$ & $0.8229 * *$ & 0.4131 & $0.6415^{* * *}$ & 0.5369 & -0.0969 & 1 & \\
\hline$\%$ Hatch & -0.0819 & 0.1365 & 0.1081 & 0.5189 & -0.4777 & $-0.5735^{*}$ & 0.1920 & -0.1152 & 1 \\
\hline
\end{tabular}

$*(\mathrm{P}<0.05) \quad * *(\mathrm{P}<0.01)$ 
positive correlation with average hatch weight, also it had a positive correlation with fertility percent but not significantly correlated. It is also noted that egg weight loss negatively correlated ( $p>0.05$ ) with percent hatch.

\section{Discussion}

The main effect of oviposition and egg size on incubation loss revealed that the initial afternoon eggs were heavier than those laid in the morning which is contrary to report of numerous studies that indicated the eggs laid in early morning were heavier than those laid later during the day (Tumová and Ebeid, 2005; Tumová et al., 2007; Tumová et al., 2009). The finding of this study is also at variance with the report of Ayorinde and Olagbuyiro (1991) that egg weight was not significantly affected by the different time of lay. Moreover, most of investigators showed that eggs had better shell quality characteristics when laid in the afternoon than in the morning (Johnston and Gous, 2007; Pavlovski et al., 2000).

The percent of egg weight loss obtained in this study $(14 \pm 2.95-17 \pm 5.74)$ were slightly higher than $11.32 \%$ recorded by Soliman et al. (1994). This implies that the incubator condition in this study could be of low humidity. It has been established that the eggs incubated in low humidity lost more than twice the egg weight loss of eggs incubated in high humidity (Soliman et al., 1994). Temperature had been reported to highly influence the relative humidity, and both contribute to water loss during incubation of eggs, therefore temperature and humidity must be carefully monitored during incubation, because the embryo is not able to control the water loss of egg (Ar, 1991). High hatchability was noted when water loss in during incubation is between 8
$-18 \%$ but lower when water loss is higher. High water loss often leads to embryonic dehydration and subsequently embryonic death (Deeming, 1995; Blood et al., 1998). This is similar to the result obtained in this study but contrary to Hassan et al. (2005) report that higher egg weight loss occurred in large eggs when compared to small egg. However, egg weight loss less than $10 \%$ or over $20 \%$ of their initial mass were reported not to likely hatch (Deeming, 1995).

Hatchability and fertility recorded in this study were not significant and contrary to the findings $65^{\circ}$ of Sarica and Soley (1995) who reported higher values for these parameters in heavy Japanese quail eggs of $(10.1-11.0 \mathrm{~g})$ than the light ones $(7.01-8.9$ g). The result on fertility corroborated the finding of Alabi et al. (2012) that chicken egg weight had no effect on fertility rate. The hatchability values obtained were higher than $71.2 \%$ that was reported by Farooq et al. (2001) as the highest hatchability in quail on the basis of fertile eggs. The higher hatchability obtained in this study could be attributed to proper turning of the eggs in the incubator and that the eggs allow an optimum rate of ventilation (Tona et al., 2001). However, the result agreed with the report of Proudfoot and Hulan (1981) who stated that egg weight did not affect the fertility and hatchability of fertile egg.

The hatch weight in this study is similar with what Yildirim and Yetisir (1998) obtained. They reported that hatching eggs of 11-11.9 $\mathrm{g}$ weight produce $6.98 \mathrm{~g}$ live weight of chick. Caglayan and Inal (2006) observed that chick's weight increased as the egg weight increased. They further showed a positive relationship between egg weight and chick-hatched weight (g) which is similar to result in this present study. The 
positive significant relationship between egg size and chick- hatched weight $(\mathrm{g})$ in this study is similar to the observation made by Alabi et al. (2012) who reported a high positive correlation between egg size and initial chick weights. The negative correlation between egg weight loss and percent hatchability obtained is similar to the findings of Sharma and Vohra (1980). The is a positive correlation between the egg size and percent hatchability was similar to the findings of Yilmaz and Caglayan (2008) who observed correlation between egg shape and weight with hatchability of quail egg. Also, Senapati et al. (1996) reported positive correlation between egg weight and hatchability

The non-significance post hatch growth response in this study was similar to the findings of Alabi et al. (2012). Pinchasov (1991) indicated that there is a decrease in the magnitude of correlation between egg weight and initial chick weight with the advancement of age of chick. However, the feed conversion ratio obtained in this study was not influenced by the oviposition time and egg size which was contrary to report of Pinchasov (1991). The author added that the egg size had a significant effect on the feed conversion ratio (FCR). The difference could be attributed to the type of birds used. Pinchasov (1991) worked on broiler chicks. A positive correlation between the egg size and egg weight loss was noted which is contrary to the findings of Hassan et al. (2005) who observed a negative correlation between egg weight and egg weight loss from his experiment on Ostrich egg.

\section{Conclusion}

This study showed that oviposition time had influence on egg weight but not on hatchability parameters. It was concluded that eggs ranging between 10.1 to 12 grams will produce higher hatch weight.
However, setting of Japanese quail eggs ranging between 8 to 12 grams irrespective of oviposition time could not affect posthatch performance of the chicks.

\section{References}

Alabi, O.J., Ngambi, J. W., Norris, D. and Mabelebele, M., 2012. Effect of egg weight on hatchability and subsequent performance of Potchefstroom Koekoek chicks. Asian J. Anim. Vet. Adv. 7: 718-725.

Ar. A 1991. Egg water movements during incubation. In: S G Tullet (editor). Avian Incubation. London, (Buterworth-Heinemann) 157-173.

Ayorinde, K. and Olagbuyiro, B.1991. The influence of clutch size and oviposition time on egg weight and egg index in Hubbard layers. Bulletin of Animal Health and Production in Africa, 39: 251-253.

Blood, J. R., Van Schalkwyk, S. J., Cleete, S. W. P. and Brand, Z. 1998. Embryonic deaths in relation to water loss of artificially incubated ostrich eggs. Pages 148-151 in: Ratites in a Competitive World. Proceedings of the 2nd International Ratite Congress, Sept. 1998. F. W. Huchzermeyer, ed. Oudtshoorm, South Africa.

Caglayan, T. and Inal, S. 2006. Effect of egg weight on hatchability, growth and survival rate in Japanese quail. Vet. Bil. Derg. 22(1-2):11-19.

Cerit, H. 1997. Genetic and phenotypic parameter of various traits in poultry. Veteriner, Istanbul, edu. Tr/ Vetfakdergi/2001-1/Makale-19.

Deeming, D. C. 1995. Factors affecting hatchability during commercial incubation of ostrich (Struthio camelus) eggs. Br. Poult. Sci. 36: 51-65. 
Farooq, M., Aneela, K., Durrani, F. R., Muqarrab, A. K., Chand, C. and Khurshid, A. 2001. Egg and shell weight, hatching and production performance of Japanese broiler quails. Sarhad J. Agric. 17 (3), 289293.

Hassan, S. M., Siam, A. A., Mady, M. E. and Cartwright, A. L. 2005. Egg storage period and weight effects on hatchability of ostrich (Struthio camelus) eggs. Poult Sci. 84:19081912.

Johnston, S. A. and Gous, R. M. 2007. Modelling the changes in the proportion of the egg components during a laying cycle. British Poultry Science 48: 347-353.

King'ori, A.M. 2011. Review of the factors that influence egg fertility and hatchability in poultry. International Journal of Poultry science 10 (6): 483492.

Metin, S. 2007. Heritability of Exterior egg quality triat Japanese quail. Applied Biological Science 1 (2): 37- 40.

Ojo, V., Ayorinde K. L, Fatoki H.O. 2011. Relationship between body weight and some egg production traits in the Japanese quail. NISEB Journal Vol. 11, N0 1.

Patterson, P. H. 1997. The relationship of oviposition time and egg characteristics to the daily light: dark cycle. Journal of Applied Poultry Research, 6, 381-390.

Pavlovski, Z., Vitorovic, D., Skrbic, Z. and Vracar, S. 2000. Influence of limestone particle size in diets for hens and oviposition time on eggshell quality. Acta Vet. Beograd, 50: 37-42.

Pinchasov, Y. 1991. Relationship between the weight of hatching eggs and subsequent early performance of broiler chicks. Brit. Poultry Sci., 32:
109-115.

Proudfoot, G. F. G. and Hulan, H. W. 1981. The influence of hatching egg size on the subsequent performance of broiler chickens. Poult. Sci. 60 (10): 2167-2170.

Reddish, J. M., Nestor, K. E. and Lilburn, M. S. 2003. Effect of selection for growth on onset of sexual maturity in randombred and growthselection lines of Japanese quail. Poultry Science 82:187-191.

SAS, 1999. SAS/STAT Users Guide Release 6.12 SAS Institute, Cary North Caroline USA.

Sarica, M. and Soley, F., 1995. The effect of hatching egg weight on the hatchability, growing and egg production traits of Japanese quail (Coturnix coturnix japonica). J. Agric. Fac. Ondokuz Mayis Univ. 10, 19-30.

Senapati, P. K., Das, K., Mondal, K. G. and Chaterjee, A. K. 1996. Relationship between e g g weight, shape index and fertility and hatchability of Japanese quail eggs. Environ. Ecol. Stat., 14: 574-577.

Sharma, P. K. and Vohra, P. 1980. Relationship between egg weight, shape index and fertility and hatchability of Japanese quail (Coturnix coturnix japonica) eggs. Indian J. poult. Sci., 15:5-10.

Soliman, F. N. K., Rizk, R. E. and Brake, J. 1994. Relationship between shell porosity, shell thickness, egg weight loss, and embryonic development in Japanese quail eggs. Poultry Science 73:1607-1611.

Tona, K., Bameli, F., Coucke, W., Bruggeman, $\mathrm{V}$. and Decuypere, E. 2001. Relationship between broiler breeder's age and egg weight loss and embryonic mortality during incubation in large-scale conditions. J. Applied 
Poult. Res. 10:221-227.

Tumová, E. and Ebeid, T. 2005. Effect of time of oviposition on egg quality characteristics in cages and in a litter housing system. Czech Journal of Animal Science 50, 129-134.

Tumová, E., Skřivan, M., Englmaierová, M. and Zita, L. 2009. The effect of genotype, housing system and collection time on egg quality in egg type hens. Czech. J. Anim. Sci., 54:1723.

Tumová, E., Zita, L., Hubený, M., Sk Ivan, M., and Ledvinka, Z. 2007. The effect of oviposition time and genotype on egg quality characteristics in egg type hens. Czech Journal of Animal Science 52, 26-30.

Woodard, A. E., Abplanalp, H., Wilson, W.
O. and Vohra, P. 1973. Japanese quail (Corturnix coturnix japonica) in the laboratory. Department of Avian Sciences University of California, Davis, CA 95616.

Yildirim, I. and Yetisir, R. 1998. Effects of hatching egg weight and parental age on the hatching weight and $6^{\text {th }}$ week live weight in Japanese quail (Coturnix coturnix japonica). Turk. J. Vet. Anim. Sci.22, 315-319.

Yilmaz, A. and Caglayan. T. 2008. Faekli tuy rengine sahip Japon bildircinlarinda (Coturnix coturnix japonica) yumurta agirligi, sekil indeksi ve cikim agirligi ile bu ozellikler arasi iliskiler. F.U. sag. Bil. Derg., 22: 05-08.

Received: 26 ${ }^{\text {th }}$ August, 2012 Accepted: $1^{*}$ February, 2013 